\title{
Toprakların Bazı Makro Besin Elementi İçeriklerinin Farklı Tarımsal Arazi Kullanımları Altında Konumsal Dağılımlarının Belirlenmesi ${ }^{* *}$
}

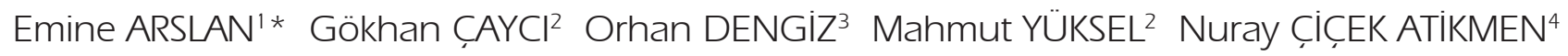

'Alata Bahçe Kültürleri Araștırma Enstitüsü Müdürlüğü, Mersin ${ }^{2}$ Ankara Üniversitesi Ziraat Fakültesi, Toprak Bilimi ve Bitki Besleme Bölümü, Ankara

${ }^{3}$ Ondokuz Mayıs Üniversitesi Ziraat Fakültesi, Toprak Bilimi ve Bitki Besleme Bölümü, Samsun

${ }^{4}$ Çankııı Karatekin Üniversitesi Orman Fakültesi, Peyzaj Mimarlığı Bölümü, Bitki Materyali ve Yetiștiriciliği Anabilim Dalı, Çankııı

\author{
*Sorumlu yazar e-mail (Corresponding author e-mail): emine.arslan23trm@gmail.com \\ Geliș tarihi (Received): 14.06.2018 \\ Kabul tarihi (Accepted): 06.08.2018 \\ DOI: $10.21657 /$ topraksu. 460723
}

\section{Öz}

Elazığ Ili Baskil İlçesi' ne bağlı Șeyh Hasan Köyü'nde yaklașık 400 hektar alan üzerinde yürütülen bu çalıșma, toprakların farklı arazi kullanımları altında, toplam azot $(N)$, yarayıșlı fosfor ( $P_{\text {av }}$ ) ve yarayıșlı potasyum $\left(\mathrm{K}_{\mathrm{av}}\right)$ içeriklerinin konumsal dağılımlarını belirlemek amacıyla gerçekleștirilmiștir. Bu amaçla, 174 farkı noktadan 0-15 cm derinlikten toprak örnekleri alınarak alansal dağılımı belirlemek için 5 farklı enterpolasyon yöntemi karșılaștırılmıș ve en iyi dağıımı veren yöntem belirlenerek toplam $N, P_{a v}$ ve $K_{a v}{ }^{\prime}$ un konumsal dağılım haritaları hazırlanmıștır. Elde edilen dağılım haritalarına göre, çalıșma alanı FAO sınıflaması dikkate alındığında toplam $N$ ve $\mathrm{K}_{\mathrm{av}}$ yönünden yeterli düzeyde belirlenmiștir. Diğer taraftan $P_{a v}$ 'ın çalıșma alanının çok az bir kısmında az düzeyde buna karșın genelde yeterli düzeyde olduğu belirlenmiștir.

Anahtar kelimeler: toplam azot, yarayıșlı fosfor, yarayıșlı potasyum, enterpolasyon

**Doktora Tezinden Özetlenmiștir.

\section{Determination of Spatial Distribution of Some Macro Nutrient contents of Soils Under Different Agricultural Uses}

\begin{abstract}
This research was carried out in Șeyh Hasan village of Baskil district of Elazığ province covering about 400 ha. It was aimed to determine spatial distribution for total nitrogen (N), available phosphorus $\left(\mathrm{K}_{\mathrm{av}}\right)$ and available potassium $\left(\mathrm{P}_{\mathrm{av}}\right)$ elements of soils under different agricultural uses. For this aim, total 174 soil samples were collected from surface depth $(0-15 \mathrm{~cm})$ in the study area. In order to determine spatial distribution of samples, five different interpolation models were applied and the most suitable model was detected. Thus, spatial distribution maps of total $N, P_{a v}$ and $K_{a v}$ were generated using the most model for each. According to obtained distribution maps, $\mathrm{N}$ and $\mathrm{K}_{\mathrm{av}}$ concentrations were sufficient by taking into consideration of FAO classes, whereas only small part of the study area was insufficient as to $P_{a v}$ concentration.
\end{abstract}

Key word: total nitrogen, available phosphorus, available potassium, interpolation. 


\section{Gíriș}

Doğada olușumu binlerce yıl süren ve üretilemeyen sınırlı temel kaynaklardan olan topraklar, farklı zaman ve mekan ölçeğinde olușumunda etkili olan doğal süreçler ile yönetim uygulamalarının bir sonucu olarak biyolojik, kimyasal ve fiziksel özellikleri bakımından büyük ölçüde değișkenlik gösterirler. Doğal değișkenlik faktörleri ile birlikte arazi kullanımı ve sürdürülebilirliği açısından toprak yönetimi gibi dıș faktörler, biyolojik göstergeler üzerinde etkili olmakla beraber farklı arazi kullanım sistemleri de toprağın mikrobiyolojik ve kimyasal özelliklerini etkileyebilmektedir (Nougeira vd., 2006).

Sürdürülebilir toprak verimliliği ve bitkisel üretim açısından topraklarda meydana gelen reaksiyonlar kadar toprakta besin elementlerinin dengesi de son derece önemlidir. Tarımsal üretimde bitkilerin optimal bir șekilde büyüme ve gelișme gösterebilmeleri için toprakta bulunması gereken zorunlu makro besin elementlerinden azot, fosfor ve potasyum seçilen toprak yönetim metotlarına bağlı olarak toprakta cereyan eden kimyasal, fiziksel ve biyolojik süreçlerde doğrudan veya dolaylı olarak rol aldıklarından toprak verimliliğini etkilemektedirler. Ayrıca bitkisel üretim için büyük öneme sahip bu bitki besin maddeleri, toprakta bitkilerin yararlanabilmeleri için çoğunlukla yeter düzeyde değillerdir. Bu nedenle, tarım topraklarının verim gücünü yükseltmek, ürünün nitelik ve niceliğini arttırmak amacıyla çeșitli șekillerde topraktan uzaklașan bitki besin maddelerinin tekrar toprağa ilave edilmesi amacıyla içerisinde bir veya birkaç besin maddesi bulunduran bileșiklerden en fazla azot, fosfor ve potasyum kimyasal gübre olarak kullanılmaktadır. Çiftçiler tarafından her bir bitki türünün topraktan her yıl aynı besin elementlerini sömürdüğü, toprağı yorduğu ve fakirleștirdiği göz önüne alınmayarak, ürün verimini arttırmak amacıyla çoğunlukla azot, fosfor, potasyum olmak üzere toprağa birçok kimyasal girdi ilave edilmektedir.

Toprak özellikleri dikkate alınmadan bilinçsizce yapılan tarımsal faaliyetlerdeki uygulamalar (gübreleme, sulama vb.), yanlıș toprak yönetimi, erozyon, çoraklașma, amaç dıșı arazi kullanımı ve toprak kirliliği sonucu tarım topraklarımızın sınırları her geçen gün daha da daralmakta, fiziksel, kimyasal ve biyolojik özellikleri tahrip olmakta ve bunlara bağlı olarak kaliteleri de azalmaktadır. Bu nedenle bitkisel üretimi maksimum seviyeye çıkarmak için toprak ve çevre șartları göz önüne alınarak iyi bir toprak yönetim sistemi ile birlikte iyi bir arazi kullanım planlanması yapılması için toprak Özelliklerinin zamansal ve konumsal değișkenliği hakkında bilgi sahibi olmak son derece önem tașımaktadır.

Toprak verimlilik özelliklerinin mekânsal olarak değișim göstermesi ve bu değișimin izlenebilme olanakları, girdi optimizasyonu sağlayan, çevreye duyarlı hassas tarım ve değișken oranlı gübre uygulamaları teknolojilerini doğurmuștur. Hassas tarım uygulamaları ile üretimde optimizasyon sağlanabilmekte, çevreye daha duyarlı tarımsal uygulamalar geliștirilebilmektedir (Güçdemir vd., 2004). Özyazıcı vd. (2016) Orta ve Doğu Karadeniz Bölgesi tarım topraklarının temel verimlilik düzeyleri ve alansal dağılımlarının belirlenmesi üzerine yaptıkları çalıșmada, tarım alanlarını temsil edecek șekilde $2.5 \times 2.5 \mathrm{~km}$ grid mesafelerde 0-20 cm toprak derinliğinden toplam 3400 adet toprak örnekleri alarak toprakların CBS (Coğrafi Bilgi Sistemleri) yardımıyla temel bazı fiziksel ve kimyasal analiz sonuçlarına ait dağılım haritaları olușturmușlardır. Araștırıcılar, bölge topraklarının \%58.83'ünde fosfor noksanlığı görürlerken, toprakların \%42.68'inde ise ekstrakte edilebilir potasyumun yeterli düzeylerde olduğunu belirlemișlerdir.

Toprak verimlilik Özellikleri mekansal değișiklik gösterdiğinden klasik istatistiki yöntemler, toprakların mekansal olarak gösterdiği bu değișkenliği ortaya koymada yetersiz kalmaktadır (Bașbozkurt vd., 2013). Bilinen klasik istatistiksel yöntemler belli bir alan içerisinde bireysel örneklerin birbirinden istatistiksel olarak bağımsız olduğunu varsaymakla birlikte örnek noktalarının uzaysal ilișkisi hakkında herhangi bir bilgi sunmamaktadır. Bu nedenle örneklenmemiș bir nokta, örneklenmiș diğer noktalardan elde edilen bilgilerden faydalanılarak tahmin edilebilmekte ve coğrafi bağımlıık söz konusu olduğundan klasik istatistiki yöntemlerin yerine jeoistatistiksel yöntemler kullanımaktadır. Jeoistatistik, örnekler arası uzaysal korelasyonu istatistiksel ve analitik olarak kullanan ve araștırmacılara oldukça yararlı bilgiler sunan öğelerden olușan enterpolasyon ve ekstrapolasyon tekniğidir (Ersoy ve Yünsel, 2008). Belli bir alan içerisinde incelenen bir toprak özelliği açısından çoğunlukla örnekleme noktaları arasındaki mesafe azaldıkça örnekler arasında bir 
ilișkinin (uzaysal korelasyon) olduğu (birbirlerini tanımlayıcı), aralarındaki mesafe arttıkça benzerliklerin azaldığı ve belirli bir mesafeden sonra örneklerin birbirleri ile ilișkili olmadığı kabul edilmektedir. Ayrıca belirli hata sınılları içerisinde alınabilecek en uygun örnekleme yoğunluğunun belirlenmesi en az örnek alınarak en fazla bilginin elde edilmesinde büyük önem tașımaktadır (Tașan ve Demir, 2017).

Günümüzdetoprağın değișken parametrelerinin alansal dağılımlarının belirlenmesi ve parametrelerle ile ilgili daha iyi değerlendirme yapılabilmesi için CBS yazııımlarına entegre edilen jeoistatistik yöntemler kullanılmaktadır. Belirli kriterlere göre sınıflandırılan veriler, bilgisayar ortamına aktarılarak CBS'nde değerlendirilmesinde enterpolasyon yöntemleri uygulanmaktadır. Konumsal enterpolasyon teknikleri ile ölçülen coğrafik veriler, tüm alana dağıtılarak alana ait dağıım haritaları elde edilmektedir (Heuvelink, 2006). Türkiye'de ve Dünya'da konumsal enterpolasyon yöntemlerinin uygulanması konusunda çeșitli alanlarda yapılmıș birçok çalıșma bulunmaktadır (Mair ve Fares, 2011; Doğru vd., 2011 ; Luo ve He, 2011 ; Arslan vd., 2012; Akyürek vd., 2013; Wang vd., 2014; Temizel, 2016).

Tarımsal faaliyetlerin optimum bir șekilde yüksek verim almaya yönelik planlanabilmesi için toprak özelliklerinin belirlenmesi ve izlenmesi gerekmektedir. Toprak değișkenlik süreçlerini ve dağılımını anlayıp yorumlamak, doğru ve etkili bir toprak yönetimi için önemlidir. Çünkü toprakta meydana gelen değișimleri göz ardı etmek, istenilmeyen sonuçlara yol açabilmektedir (Behera ve Shukla, 2015). Topraklardaki mekansal değișiklik, doğal toprak olușum süreçlerinden kaynaklandığı gibi insan aktivitelerinden de kaynaklanabilmektedir. Tarımsal üretimde toprağa çeșitli kimyasal ve organik girdilerin ilave edilmesi, bazı önemli elementlerin çeșitli yollarla topraktan uzaklașması, kullanılan tarım ilaçları ve yetiștirilen ürünler toprak değișkenliği üzerinde oldukça etkilidir. Elazığ Ili Baskil İıçesi' ne bağlı Șeyh Hasan Köyünde yaklașık 400 hektar alan üzerinde yürütülen bu çalıșmayla, toprakların farklı arazi kullanımlar altında, toplam azot $(\mathrm{N})$, yarayıșlı fosfor $\left(\mathrm{P}_{\mathrm{av}}\right)$ ve yarayıșlı potasyum $\left(\mathrm{K}_{\mathrm{av}}\right)$ içeriklerinin konumsal dağıımlarının belirlenmesi amaçlanmıștır.

\section{MATERYAL VE YÖNTEM}

\section{Çalıșma alanın konumu, toprak ve iklim özellikleri}

Araștırma, Doğu Anadolu Bölgesi'nde Elazığ ili' ne bağlı Baskil IIıçesinde yer alan, batı sınıı Karakaya Baraj Gölü' ne dayanan ve Șeyh Hasan Köyü sınırları içerisinde kalan alanda yürütülmüștür. Çalıșma alanının içerisinde bulunduğu Șeyh Hasan Köyü Elazığ Ili' ne 81 km, Baskil İlçesi'ne $43 \mathrm{~km}$ uzaklıktadır. Çalıșma alanı $38^{\circ} 33^{\prime} 42^{\prime \prime}$ $-38^{\circ} 32^{\prime} 09^{\prime \prime}$ kuzey enlemleri ve $38^{\circ} 23^{\prime} 42^{\prime \prime}$ - $38^{\circ} 25^{\prime} 45^{\prime \prime}$ doğu boylamları arasında yer almakta olup yaklașık 400 ha'dır (Șekil 1). Alanın haritalama çalıșmalarında 6 derecelik dilimdeki Universal Transverse Mercator (UTM) ile WGS-84 (World Geodetic System 1984) datumu kullanılmıș olup Dilim Orta Meridyeni (bölge/zone) 37 olarak alınmıș ve olușturulan haritalar kadastral haritalara uyumlu hale getirilmiștir.

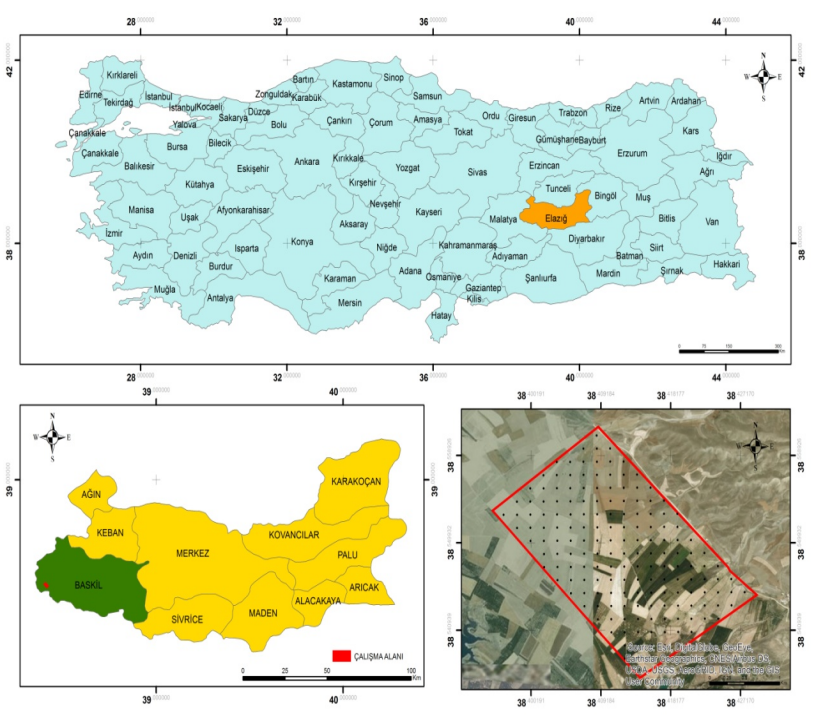

Șekil 1. Çalıșma alanına ait lokasyon haritası

Figure 1. Location map of the study area

Doğu Anadolu Bölgesi'nde, Elazığ Illi'ne bağlı bir ilçe olan Baskil'in kuzeyinde Keban, doğusunda Sivrice ve Elazığ Merkez IIlçeleri, batısında ve güneyinde Malatya ili bulunmaktadır. Ilıçede, yazların sıcak ve kurak, kıșların soğuk ve kar yağıșlı geçtiği karasal iklim egemendir. Çalıșma alanının bulunduğu köyün iklimi de bu karasal iklimin etki alanı içerisinde olmakla beraber Baraj Gölü' nün etkisi nedeniyle ılıman iklim özellikleri de tașımaktadır. Yıllık ortalama yağıș ve sıcaklık miktarları $408 \mathrm{~mm}$ ve $13.2^{\circ} \mathrm{C}$ dir. Toprak taksonomisine göre (1999) toprak sıcaklık 
ve nem rejimleri ise sırasıyla Mesic ve Xeric olarak belirlenmiștir.

Araștırma alanı çoğunlukla düz-düze yakın ve hafif eğimli olup (\%2-\%4), kuzey doğu kesimlerinde eğim \%12 üzerine çıkmaktadır (Șekil 2). Sel alma tehlikesine sahip değildir ve alanda göllenme görülmemektedir. Yüzey akıșı çok az veya çok yavaștır. Karakaya Baraj Gölü kıyı șeridinde yer alan çalıșma sahasını alüvyal (Kuvaterner) malzeme yüzeylemektedir (Turan ve Bingöl, 1991). Çalıșma alanı içerisinde bulunan araziler genellikle çevresinden alçak yerlerdedir. Çalıșma alanının ortalama denizden yüksekliğı 690 m ile 760 m arasında değișmektedir (Șekil 2).

Șeyh Hasan Köyü sınırları içerisinde bulunan çalıșma alanı ürün dağııma göre farklı alan büyüklüklerine sahip toplam 171 parselden
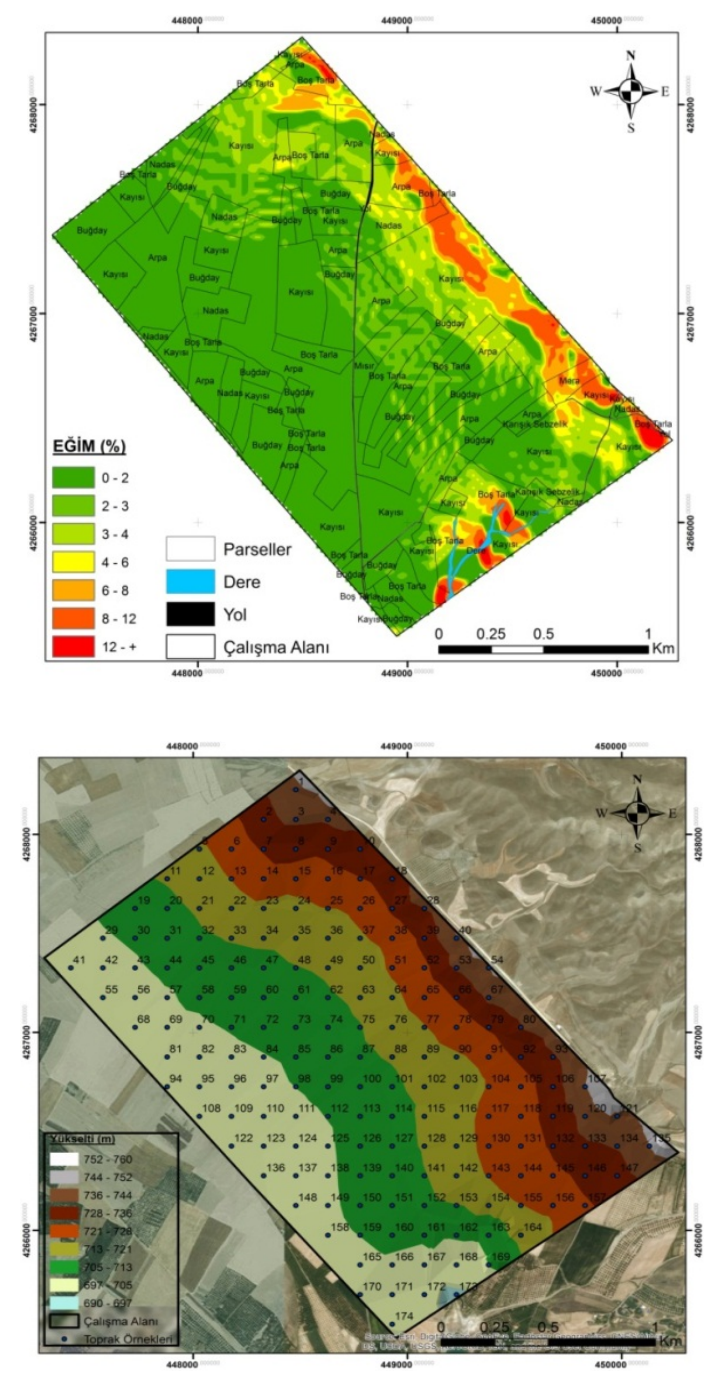

Șekil 2. Çalıșma alanı eğim ve yükselti dağılım haritası

Figure 2. Slope and elevation distribution maps of the study area
Çizelge 1. Çalıșma alanı arazi kullanımı alansal ve oransal dağılımı

Table 1 Spatial and ration distribution of the land use in the study area

\begin{tabular}{lcc}
\hline \multirow{2}{*}{ Aurazi Kündanımı/ } & \multicolumn{2}{c}{ Ekili/Dikili Alan } \\
\cline { 2 - 3 } \multicolumn{1}{c}{ (ha) } & $\%$ \\
\hline Arpa & 99.8 & 24.94 \\
Boș Tarla & 47.1 & 11.77 \\
Buğday & 51.1 & 12.77 \\
Karıșık Sebzelik & 1.2 & 0.30 \\
Kayısı & 165.4 & 41.34 \\
Mera & 2.9 & 0.72 \\
Mısır & 1.8 & 0.45 \\
Nadas & 25.9 & 6.47 \\
Diğer (Dere. yol vb. ) & 4.9 & 1.22 \\
\hline Toplam & 400.021 & 100 \\
\hline
\end{tabular}

olușmaktadır. Toprak ișlemeli tarım yapılan parsellerin toplam alanı 400.02 ha' dır. Toprak ișlemesi çeșitli toprak ișleme aletleri kullanılarak farklı sürüm dönemlerinde $10-25 \mathrm{~cm}$ derinlikler arasında yapılmaktadır. 2015 yılı üretim sezonunda 171 parselde kayısı, buğday, arpa, mısır ve karıșık sebzelik alanlarda biber, domates ve patlıcan olmak üzere 7 farklı bitkinin üretimi yapılmıștır. Çalıșma sahası içerisinde ürün olarak en fazla yaklașık 165 hektar alanda kayısı, en az ise yaklașık 1.5 hektar alanda ise karıșı sebze yetiștirilmektedir (Çizelge 1, Șekil 3). Tarım arazilerinin dıșında çalıșma alanı içerisinde mera, vasfı tarla olan boș (kullanılmayan) araziler ile Hazine Arazileri de bulunmaktadır. Bitkisel üretim sırasında çiftçiler tarafından yoğun olarak özellikle amonyum nitrat,

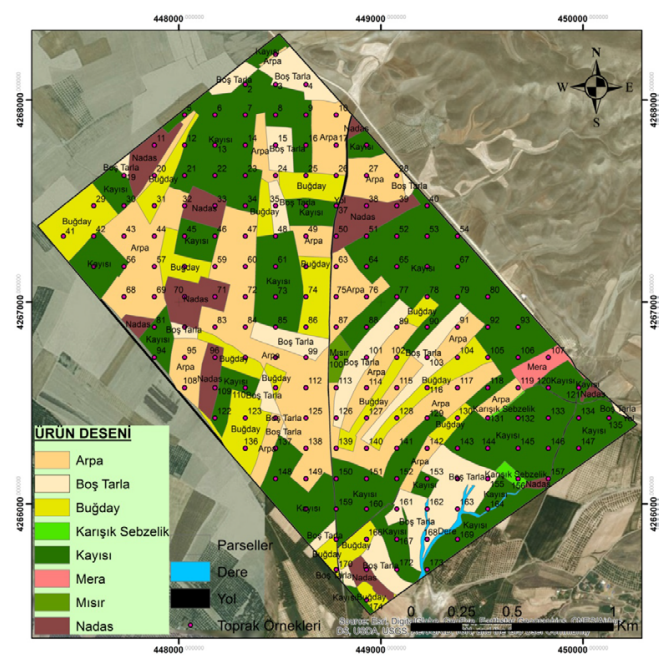

Șekil 3. Çalıșma alanı arazi kullanım deseni

Figure 3. Land use pattern of the study area 
amonyum sülfat, üre, diamonyum fosfat (DAP), triple süper fosfat (TSP), 20-20-0, 15-15-0 olmak üzere 7 farklı kimyasal gübre çeșidi kullanıldığı belirlenmiștir.

\section{Toprak Örnekleri ve Analizler}

Çalıșma alanında dağılım gösteren toprakların azot, fosfor ve potasyum içeriklerini belirlemek amacıyla hazırlanmıș olan örnekleme planına göre örnekleme noktaları arazi içerisinde Total Station aleti ile belirlenmiștir (Șekil 4). Total Station aleti hem mesafe hem de koordinat okuma özelliğine sahip olması nedeni ile arazi çalıșmasında örnek

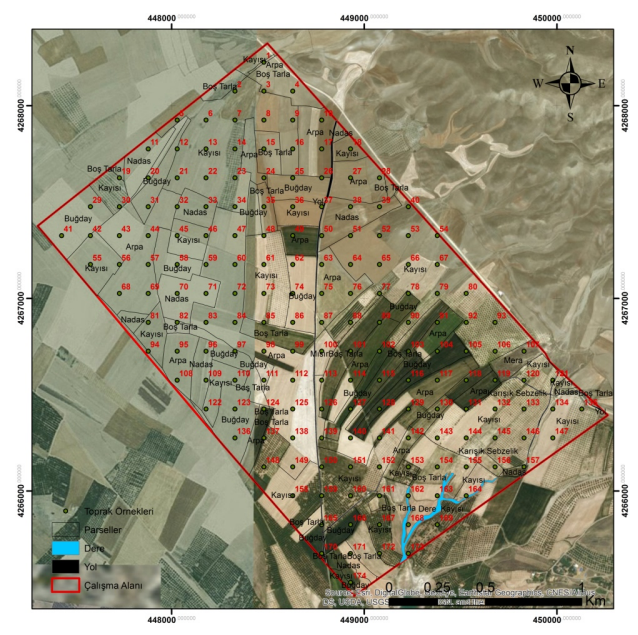

Șekil 4. Çalıșma alanındaki toprak örnekleme deseni Figure 4. Soil sampling pattern of the study area

Çizelge 2. Toprakların eșik değerlerine göre sınıflandırıması (FAO, 1990)

Table 2 Classification of the soils according to their threshold

\begin{tabular}{ccc}
\hline Besin Elemetleri & Sınır Değerleri & Tanımlama \\
\hline & $<0.045$ & Cok az \\
& $0.045-0.09$ & Az \\
Toplam N (\%) & $0.09-0.17$ & Yeterli \\
& $0.17-0.32$ & Fazla \\
& $>0.32$ & Cok fazla \\
\hline & $<2.5$ & Cok az \\
& $2.5-8.0$ & Az \\
$P_{\text {av }}\left(\mathrm{mg} \mathrm{kg}^{-1}\right)$ & $8.0-25.0$ & Yeterli \\
& $25.0-80.0$ & Fazla \\
& $>80.0$ & Cok fazla \\
\hline & $<50$ & Cok az \\
& $50-140$ & Az \\
$\mathrm{K}_{\mathrm{av}}\left(\mathrm{mg} \mathrm{kg}^{-1}\right)$ & $140-370$ & Yeterli \\
& $370-1000$ & Fazla \\
& $>1000$ & Cok fazla \\
\hline
\end{tabular}

noktalarının yerlerinin koordinat düzleminde belirlenmesi ve arazide $150 \times 150 \mathrm{~m}$ lik grid düzleminin olușturulması amacıyla kullanılmıștır

Çalıșma alanı içerisinde doğu ve güneydoğu doğrultusunda 150 m' lik mesafelerle grid-ıgara sistemi oturtturularak her karenin köșe noktalarına gelen 174 adet poligon noktası belirlenmiștir. 2015 yılı sonbaharında hasat sonrası yapılan arazi çalıșması ile daha önce belirlenen noktalarda 0-15 cm derinlikten toprak örnekleri alınmıștır. Alınan bozulmuș toprak örneklerinde toplam N, $\mathrm{P}_{\mathrm{av}}$ ve $\mathrm{K}_{\mathrm{av}}$ analizleri yapılmıștır.

Alınan 174 adet toprak örneklerinde toplam azot (N) Kjeldahl yöntemine göre (Bremner, 1982), alınabilir potasyum $\left(K_{a v}\right)$ içerikleri Jackson (1958)' e göre, alınabilir fosfor $\left(P_{a v}\right)$ ise Olsen vd. (1954) tarafindan belirtilen yönteme göre belirlenmiștir. Ayrıca toprakların toplam $\mathrm{N}, \mathrm{P}_{\mathrm{av}}$ ve $\mathrm{K}_{\mathrm{av}}$ yeterlilik düzeylerine yönelik olarak Çizelge $2^{\prime}$ den yararlanılmıștır.

\section{Tanımlayıcı İstatistik Yöntemleri}

Yapılan çalıșmada, arazi tespitleri ve laboratuvar analizlerinden elde edilen veriler kullanılarak örnekleme yapılan alanlardaki toprakların toplam $N,\left(P_{a v}\right)$ ve $\left(K_{a v}\right)$ verilerinin en büyük, en küçük, standart sapma, varyasyon katsayısı, ortalama, çarpıkık ve basıkık gibi tanımlayıcı parametreleri SPSS programı yardımı ile hesaplanmıștır.

\section{Enterpolasyon Yöntemleri}

Toprak analizlerinden elde edilen noktasal verilerin alansal dağıımını belirlemek için enterpolasyon modelleri kullanılması suretiyle en uygun model belirlenerek çalıșma alanı topraklarının toplam $\mathrm{N}$, $\left(\mathrm{P}_{\mathrm{av}}\right)$ ve $\left(\mathrm{K}_{\mathrm{av}}\right)$ içeriklerinin dağılım haritaları üretilmiștir. Çalıșma alınında koordinatları belirlenmiș örnekleme noktalarından alınan toprak örneklerinin analiz sonuçları ve çalıșma alanının coğrafik verileri enterpolasyon metotları kullanılarak ArcGIS 10.2.2 programı ile konumsal dağıım haritaları hazırlanmıı̦tır.

$\mathrm{Bu}$ çalıșma kapsamında deterministik yöntemlerden Radyal Tabanlı Fonksiyon (RBF), Ters Mesafe Ağılıklı Enterpolasyon (IDW) yöntemi, stokastik yöntemlerden Ordinary Kriging (OK), Basit Kriging (SK), Universal Kriging (UK) metotları karșılaștırılmıștır. Çalıșmada IDW metodunda birinci, ikinci ve üçüncü kuvvet (IDW-1, IDW2, (DW-3), RBF metodunda Düzeltilmiș Spline (Completely Regularized Spline, CRS), Ince Plaka 
Spline (Thin Plate Spline, TPS), ve Spline With Tension (ST) modelleri, kriging metotlarında ise Küresel (Spherical), Üssel (Exponential) ve Gaussian modelleri kullanılmıștır.

ArcGIS 10.2.2 "Geosatistical Extension" programı, üretilen haritalarda tahminin ortalama hatası (ME) ve tahminin standardize ortalama hatalar karekökü kriterlerini kullanmaktadır (RMSE) (Celik ve Dengiz, 2018). Hazırlanan haritalarda, tahminin ortalama hatası $0^{\prime}$ a yakın ve tahminin standardize ortalama hatalar karekökü ise 1' e ne kadar yakın ise haritanın aynı oranda doğru olduğu anlașılmaktadır (Johnston vd., 2001).

\section{Yöntemlerin Değerlendirme}

\section{Karșılaștırılması}

ve

Yöntemler arasında en uygun yöntemin seçilmesinde daha geniș ifade ile ölçülen değerler ile enterpolasyonlar sonucu tahmin edilen değerler arasındaki ilișkiyi sorgulayabilmek ve ölçülen değerlere en yakın sonucu veren yöntemi seçebilmek için literatürde farklı karșılaștırma yöntemlerinin de göz önünde bulundurulduğu görülmektedir (Emadi ve Bagnernejad, 2014). Yöntemlerin karșılaștırılması ve değerlendirilmesinde genel olarak en yaygın kullanılan yöntemler; Ortalama Hata Kareleri Toplamının Karekökü (RMSE) ve ortalama mutlak hata (MAE), tahmin edilen ve gözlenen değerler arasındaki korelasyon değerlerinin kullanııdığı yöntemlerdir. Bu çalıșmada en uygun yöntemlerin seçilebilmesi için yöntemlerin karșılaștırmalarında Ortalama Hata Kareleri Toplamının Karekökü (RMSE) yöntemi kullanılmıștır. Model belirlemede ise en düșük RMSE değerini veren yöntem en uygun yöntem olarak değerlendirilmiștir. RMSE değerlerinin hesaplanmasında așağıdaki Eșitlik 1. kullanılmıștır (Ding vd., 2011 ).

$$
\text { RMSE }=\sqrt{\frac{\sum\left(L_{{ }_{*}-} L_{i}\right)^{2}}{\mathrm{n}}}
$$

Eșitlikte; $Z_{i}$ : tahmin edilen değer, $Z_{i}{ }^{*}$ ölçülen değer be $n$ örnek sayısını ifade etmektedir.

\section{BULGULAR VE TARTIȘMA}

\section{Tanımsal İstatistik}

Araștırma alanı içerisinde bulunan örnekleme noktalarından 0-15 cm derinlikten alınan toprakların toplam $\mathrm{N}, \mathrm{P}_{\mathrm{av}}$ ve $\mathrm{K}_{\mathrm{av}}^{\prime}$ un analiz sonuçlarına ait tanımlayıcı istatistikler Çizelge 3'
Çizelge 3. Çalıșma alanı toprak örneklerinin tanımlayıcı istatistik parametreleri

Table 3 Descriptive statistics parameters of the soil samples in the study area

\begin{tabular}{lccc}
\hline Tanımsal İstatistik & $\begin{array}{c}\mathrm{N} \\
(\%)\end{array}$ & $\begin{array}{c}\mathrm{P} \\
\left(\mathrm{mg} \mathrm{kg}^{-1}\right)\end{array}$ & $\begin{array}{c}\mathrm{K} \\
\left(\mathrm{mg} \mathrm{kg}^{-1}\right)\end{array}$ \\
\hline $\begin{array}{l}\text { Ortalama } \\
\text { Standart Sapma }\end{array}$ & 0.19 & 12.28 & 500.94 \\
Değișkenlik & 21.05 & 8.00 & 220.14 \\
Katsayısı, \% & 65.15 & 43.95 \\
Varyans & 0.00 & 64.07 & 48461.10 \\
En Düșük Değer & 0.06 & 2.47 & 149.78 \\
En Yüksek Değer & 0.33 & 61.27 & 1395.80 \\
Çarpıklık * & 0.00 & 3.06 & 1.23 \\
Basıklık & 1.53 & 14.05 & 2.00 \\
$\mathrm{n}$ (Örnek sayısı) & 174 & 174 & 174 \\
\hline
\end{tabular}

${ }^{*}$ Carpılklık $<1 \pm 0.51=$ Normal Dağılım, 0.5-1.0 = Veri setine kadar dönüșümü uygulanır. CK\> $1.0 \rightarrow$ Logaritma dönüșümü uygulanır.

de sunulmuștur. Çizelge 3'de çalıșma alanına ait toprak örneklerinden elde edilen verilerin tanımsal

istatistikleri değerlendirildiğinde; verilen çarpıkık katsayılarına göre toplam N için normal dağıım gösterdiği $P_{a v}$ ve $K_{a v}$ için ise normal dağılımdan uzak (log normal) pozitif çarpıklık gösterdiği görülmektedir. Pozitifçarpıklık katsayıları, incelenen toprak özelliklerinin ortalamanın üzerinde așırı uç değerlere sahip olduğunu gösterirken, toprak özelliklerinde ortaya çıkan bu farklı değerler, toprak özelliklerine ait değișkenlik katsayılarının da farklı olmasını sağlamaktadır.

Wilding (1985)' e göre değișkenlik katsayısı \%15 den az olanlar düșük, \%15-35 arası olanlar orta ve \%35 den fazla olanlar ise değișkenliği yüksek olarak nitelendirilmektedir. Buna göre çalıșma alanı toprak örneklerinde toplam $\mathrm{N}$, $P_{a v}$ ve $K_{a v}$ değișkenlik katsayılarına bakıldığında, toplam azotun orta değișkenliğe sahipken, $P_{a v}$ ve $K_{a v}$ un yüksek değișkenliğe sahip olduğu görülmektedir. Araștırma alanının hakim toprak yapısını alüvyal topraklar olușturmaktadır. Alüvyal arazilerde toprak özelliklerinin en önemli özelliği kısa mesafelerde yüksek değișkenlik göstermesinin beklenilmesidir. Ayrıca, toprakların yoğun tarımsal faaliyetler altında olmalarının özellikle makro besin elmenlerindeki değișkenliğin nedeni olduğu düșünülmektedir.

Coğrafi Bilgi Sistemleri ve Enterpolasyon Yöntemleri 
Çizelge 4. Çalıșma alanı topraklarının enterpolasyon yöntemlerine ait RMSE değerleri

Table 4 RMSE values of the interpolation methods for the study area's soils

\begin{tabular}{|c|c|c|c|c|c|c|c|c|c|c|c|c|c|c|c|}
\hline & \multicolumn{3}{|c|}{ IDW } & \multicolumn{3}{|c|}{ RBF } & \multicolumn{9}{|c|}{ Kriging } \\
\hline & 1 & 2 & 3 & TSP & CRS & TS & & OK & & & SK & & & UK & \\
\hline & & & & & & & $\mathrm{G}$ & Ü & $\mathrm{K}$ & $\mathrm{G}$ & $\ddot{U}$ & K & $\mathrm{G}$ & $\ddot{U}$ & K \\
\hline $\begin{array}{l}N \\
(\%)\end{array}$ & 0.04 & 0.03 & 0.03 & 0.04 & 0.03 & 0.03 & 0.03 & 0.03 & 0.03 & 0.03 & $\underline{0.03}$ & 0.03 & 0.03 & 0.03 & 0.03 \\
\hline $\begin{array}{l}\mathrm{P} \\
(\mathrm{mg} \\
\left.\mathrm{kg}^{-1}\right)\end{array}$ & 7.54 & 7.77 & 8.11 & 9.76 & 8.15 & 7.92 & 7.48 & 7.52 & 7.51 & 7.47 & 7.60 & 7.48 & 7.48 & 7.52 & 7.51 \\
\hline $\begin{array}{l}\mathrm{K} \\
(\mathrm{mg} \\
\left.\mathrm{kg}^{-1}\right)\end{array}$ & 165.8 & 163.3 & 162.6 & 177.0 & 162.6 & 162.5 & 166.8 & 161.9 & 163.2 & 165.3 & 162.3 & 163.6 & 166.8 & 162.9 & 163.2 \\
\hline
\end{tabular}

G: Gaussian, Ü: Üssel, K: Küresel. Tabloda kalın siyah ve altı çizili olarak yazılan değerler uygun enterpolasyon yöntemi olarak seçilen en küçük kare kök ortalama hata değerlerine ait verilerdir. OK: Doğal, SK: Basit, UK: Evrensel

Toprak analizlerinden elde edilen noktasal verilerin alansal dağıımını belirlemek için enterpolasyon modellerinden en çok kullanılan deterministik yöntemlerden IDW, RBF, stokastik yöntemlerden Ordinary Kriging (OK), Basit Kriging (SK), Universal Kriging (UK) metotları kullanılarak sonuçlar karșılaștırılmıș olup en düșük Ortalama Hata Kareleri Toplamının Karekökü (RMSE) değerini veren yöntem en uygun yöntem olarak seçilmiștir. Çizelge 4 incelendiğinde; toplam N ve $P_{a v}$ değerleri için en düșük RMSE değerlerinin SK yönteminde toplam $N$ için Üssel, $P_{a v}$ için ise Gaussian modellerinden elde edildiği,

$\mathrm{K}_{\mathrm{av}}$ değerlerin en uygun alansal dağılımı için ise en iyi yöntemin OK yönteminde Üssel model olduğu görülmektedir.

\section{Toplam Azot Dağılımı}

Toprak azotunun kaynağını atmosferdeki azot ile birlikte toprak organik maddesi veya humus olușturmaktadır. Toprak azotunun \% 92-96'sı organik azottur. Tarımsal üretimde bitkilerin optimal bir șekilde büyüme ve gelișme gösterebilmeleri için toprakta bulunması gereken zorunlu makro besin elementlerinden azot, seçilen toprak yönetim metotlarına bağlı olarak toprak verimliliğini önemli derecede etkilemektedir.

Yoğun tarımsal üretim ortamı olarak kullanılan çalıșma alanı topraklarının toplam azot miktarı $\% 0.06$ ile \% 0.33 arasında değișim göstermektedir (Çizelge 3). Ayrıca, 174 toprak örneğinin toplam azot değerlerinin ortalama olarak yeterli ve fazla sınıf aralığına girmiș olduğu belirlenmiștir.
Topraklarda toplam azot içeriğinin değișkenliğinin daha hassas bir șekilde özellikle azotlu gübre yönetimi açısında değerlendirildiğinde, toplam azotun alansal dağılım haritası yedi farklı sınıf aralığında incelenmiștir (Șekil 5). Toplam azot dağııım haritasına göre, toprak örneklerinin azot içeriklerinin özellikle \%0.16-0.20 değerleri arasında yoğun dağılım gösterdiği belirlenmiștir. Toplam azotun nispeten daha az olduğu alanlar genellikle araștırma alanının doğusunda ve orta kısımlarında, çok fazla olduğu alanlar ise kuzeyinde ve güneyinde dağılım göstermektedir. Toplam azotun yeterli ve fazla olduğu alanlarda yoğun kimyasal gübre kullanımı ile birlikte yoğun toprak ișlemeli tarım yapıldığı tespit edilmiștir. Özellikle ürün verimini arttırmak kaygısıyla kayısı bahçesi

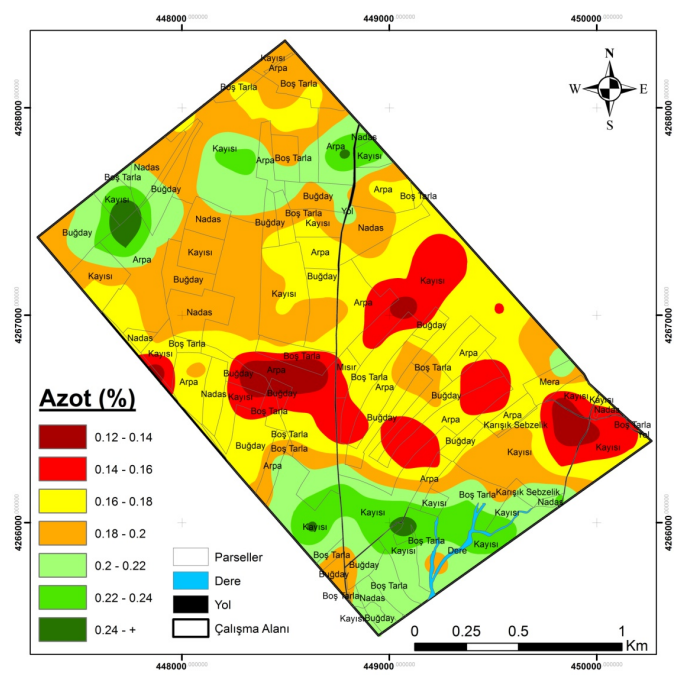

Şekil 5. Çalıșma alanında toplam azot dağılım haritası

Figure 5. Distribution map of total nitrogen in the study area 
alanlarında așırı azotlu gübre uygulamalarına bağlı olarak azot fazlalığı yoğun görülmektedir.

\section{Alınabilir Fosfor Dağılımı}

Fosfor toprak verimliliğinin bir göstergesidir. Bitkinin kök gelișimi, olgunlașması, döllenme, erken tohum teșekkülü ve hastalık ve zararlılara karșı direnci arttırdığından çok önemli bir makro besin elementidir. Fosforun topraktaki fiksasyonu fazla olduğundan bitki açısından da elverișliliği doğal ortam șartlarına ve toprak yönetim uygulamalarına göre oldukça değișkenlik göstermektedir.

Çalıșma alanında yer alan toprakların $P_{a v}$ içerikleri $2.47 \mathrm{mg} \mathrm{kg}^{-1}$ ile $61.27 \mathrm{mg} \mathrm{kg}^{-1}$ arasında değișmektedir (Çizelge 3). 174 toprak örneğinde $P_{a v}$ az ve yeterli sınır değeri arasında değișim göstermekte olup ortalama $12.28 \mathrm{mg} \mathrm{kg}^{-1}$ dir. Toprakların $P_{a v}$ içeriğinin değișkenliğinin daha hassas bir șekilde incelenebilmesi için alansal dağııım haritalarında on farklı sınıf aralığında dağılımları belirlenmiștir (Șekil 6). Dağılım haritasına göre, toprak örneklerinin $P_{a v}$ içeriklerinin çok az ile fazla arasında farklılık göstermekle birlikte, 8.19 mg $\mathrm{kg}^{-1}-13.67 \mathrm{mg} \mathrm{kg}^{-1}$ arasında olan az ve yeterli düzey değerleri arasında yoğunlaștığı belirlenmiștir. Fosforun az olduğu alanlar genellikle araștırma alanının güney doğusunda ve en az olduğu sınır değerlerinde özellikle tarla alanlarında, çok fazla olduğu alanlar ise kuzey doğusu ve kuzey batısında yer almaktadır. Ayrıca fosforun en yüksek sınır değerleri de, yoğun olarak kayısı bahçelerinde dağıım göstermektedir.

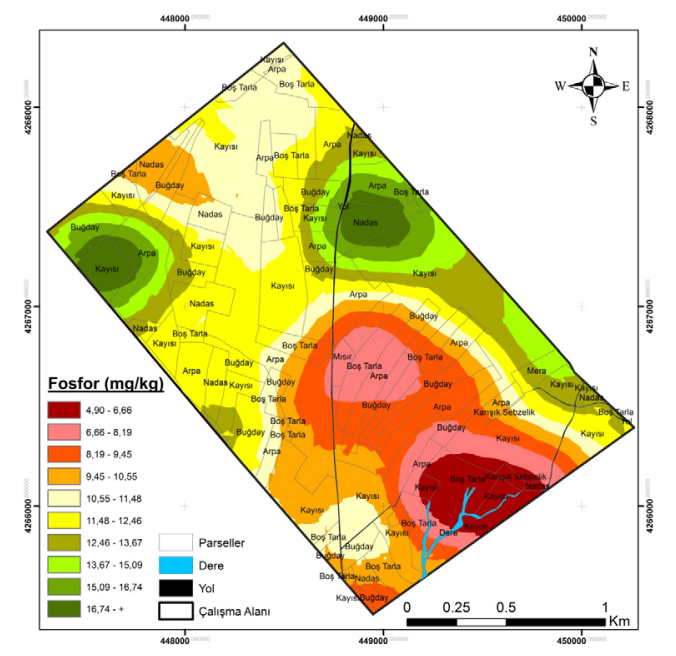

Șekil 6. Çalıșma alanında alınabilir fosfor $\left(P_{a v}\right)$ dağıım haritası

Figure 6. Distribution map of available phosphorus $\left(P_{a v}\right)$ in the study area.

\section{Alınabilir Potasyum Dağılımı}

Potasyumun toprakta tutulması veya tekrar bitkiler için yarayıșlı forma dönüșmesi süreci henüz tam anlamıyla açıklığa kavușturulamamıștır (Bilen ve Sezen, 1993). Buna rağmen topraktaki potasyumun dinamik yapısını toprak reaksiyonlarındaki değișimlerin etkilediği bilinmektedir. Toprakların kil miktarı ve çeșidi, kireç içeriği, pH değeri gibi diğer bazı toprak özelliklerinin toprakta potasyumun serbest bırakılması veya tutulması (fikse edilmesi) gibi süreçler üzerinde etkili olmasından dolayı potasyumun toprakta dağıımı değișkenlik göstermektedir.

Çalıșma alanında yer alan toprakların $\mathrm{K}_{\mathrm{av}}$ içerikleri $149.78 \mathrm{mg} \mathrm{kg}^{-1}$ ile $1395.80 \mathrm{mg} \mathrm{kg}^{-1}$ arasında değișmektedir (Çizelge 3). Çizelge 2' deki sınır aralık değerleri dikkate alındığında topraklar $\mathrm{K}_{\mathrm{av}}$ bakımından yeterli ve çok fazla sınır değerleri arasında sınıflanmaktadır. Toprakların $\mathrm{K}_{\mathrm{av}}$ içeriğinin değișkenliğinin daha hassas bir șekilde incelenebilmesi için alansal dağılım haritalarında 10 farklı sınıf aralığı belirlenmiștir (Șekil 7). Yapılan analiz sonuçlarına göre toprak örneklerinin $\mathrm{K}_{\mathrm{av}}$ içerikleri, çalıșma alanının güneydoğusunda küçük bir alanda $200-250 \mathrm{mg} \mathrm{kg}^{-1}$ yeterli sınır değerleri arasında, buna karșın önemli bir bölümü çalıșma alanının batı ve güneybatısında $450-800 \mathrm{mg} \mathrm{kg}^{-1}$ sınır değerleri arasında yoğunlașarak dağıım göstermektedir. $K_{a v}$ dağıımının, arazi kullanımına bağlı olarak yer yer değișkenlik göstermekle birlikte artan kil oranına bağı olarak en yüksek sınır değerlere ulaștığı tespit edilmiștir.

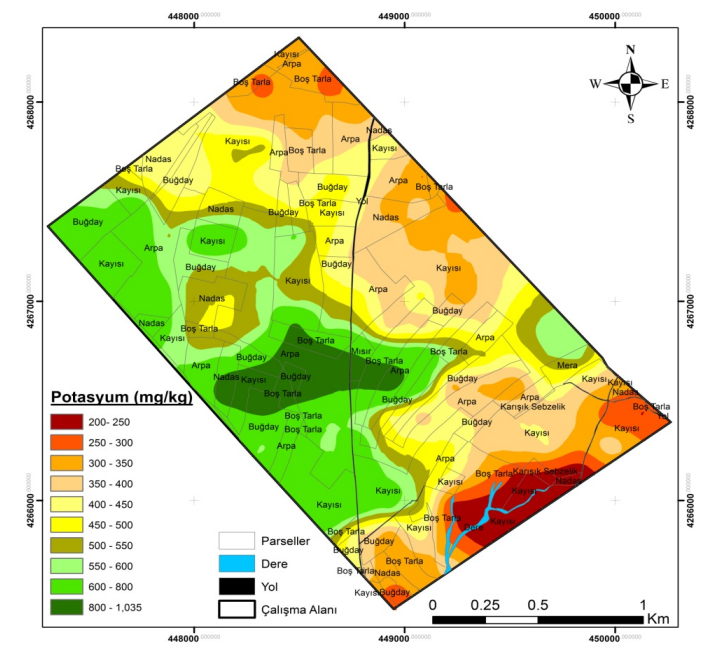

Șekil 7. Çalıșma alanında alınabilir potasyum $\left(K_{a v}\right)$ dağılım haritası

Figure 7. Distribution map of available potassium $\left(K_{a v}\right)$ in the study area 


\section{SONUÇ VE ÖNERILER}

Bu çalıșmada, sulu ve kuru tarım yapılan yaklașık 400 ha alanda 174 farklı örnekleme noktasında yüzey toprak derinliğinden $(0-15 \mathrm{~cm})$ alınan toprak örneklerinin, toplam $\mathrm{N}, \mathrm{P}_{\mathrm{av}}$ ve $\mathrm{K}_{\mathrm{av}}$ içeriklerinin mesafeye bağlı ilișki ve değișimlerinin en uygun enterpolasyon yöntemle konumsal dağılımları belirlenmiștir. Böylece olușturulan haritalar, arazi kullanım desenini gösteren parsel haritası ile coğrafi bilgi sitemi ortamında birleștirmek suretiyle değișimin olumlu ya da olumsuz etkilendiğinin ortaya konulması ve olumsuz etkilenen alanlarda ne gibi tedbirlerin uygulanması gerektiği gibi önerilerde bulunulması için önemli bir kaynak olușturmuștur. Bu amaçla IDW, RBF, SK, UK ve OK yöntemleri test edilmiștir. Doğrulamalarda toplam $N$ ve $P_{a v}$ değerlerinin dağııımında en düșük RMSE değerleri veren SK, $K_{a v}$ değerlerinin dağılımında ise en düșük RMSE değerleri veren OK yöntemleri en iyi sonuç vermiștir.

Tarımsal üretimde yüksek oranda ve kaliteli ürün elde edilmesi açısından bitkinin intiyaç duyduğu bitki besin elementlerinin toprağa yeterli miktarlarda ve usulüne uygun olarak verilmesi oldukça önem arz etmektedir. Yapılan değerlendirmeler doğrultusunda çalıșma alanında yer yer bazı örnekleme noktalarında az olmakla beraber toprakların genelinde azot içeriğinin yeterli veya fazla olduğu görülmektedir. Yapılan arazi tespit çalıșmaları ve toprakların analizinden elde edilen sonuçlar değerlendirildiğinde, azot kaynağının yalınızca az bir kısmının organik madde kaynaklı olduğu anlașılmıș olup, özellikle çiftçiler tarafından bilinçsizce yapılan yanlıș zamanda, așırı azotlu gübre (amonyum nitrat, amonyum sülfat, DAP, Üre) uygulamaları nedeniyle topraklarda azot fazlalığı görülmektedir. Toprakta yetersiz azot bitki gelișmesini olumsuz etkilerken așırı miktarlardaki azot içerikleri de bitki gelișimini olumsuz yönde etkilemektedir. Ayrıca, topraktan yıkanma yoluyla olan azot kayıpları taban suları, göl ve baraj gibi su kütlelerine erișmeleri ile çevresel kirlenmelere de sebep olabilmektedir. Dolayısıyla bu durum gerek ekolojik gerekse de ekonomik olarak olumsuz sonuçlara neden olabilmektedir.

Benzer durum araștırma alanının fosfor ve potasyum içeriği için de geçerlidir. Çalıșma alanı topraklarının genelinde potasyum içeriğinin yeterli ve fazla sınıf aralığında yoğunlaștığı belirlenmiștir. Çalıșma alanı topraklarının potasyumca zengin olması dolayısıyla potasyumlu gübre uygulamaları önerilmemektedir. Araștırma alanı içerisinde yalnızca yaklașık 115 hektar alanda 50 örnekleme noktasında toprakların fosfor içeriği çok az ve az sınıfta değerlendirilmektedir. Bu bölgelerde intiyaç duyulan miktarda ve doğru uygulama zamanında fosfor içerikli ticari gübrelerin uygulanması gerekmektedir.

Sonuç olarak bu araștırmada elde ettiğimiz bulgular arazi kullanımı ile toprak özelliklerinin de değiștiğini ortaya koymaktadır. Bu değișimler ve bitki özellikleri dikkate alınarak söz konusu alanlarda gübre yönetim planlamasını gerçekleștirmek, bașarılı bir toprak yönetiminin önemli öğelerinden biri olacaktır.

\section{KAYNAKLAR}

Akyürek Ö, Arslan O, Karademir A (2013). SO2 ve PM10 hava kirliliği parametrelerinin CBS ile konumsal analizi: Kocaeli örneği, TMMOB Harita ve Kadastro Mühendisleri Odası Ulusal Coğrafi Bilgi Sistemleri Kongresi, 1 1-13 Kasım, Ankara.

Arslan H, Cemek B, Güler M, Yıldırım D (2012). Değișebilir sodyum yüzdesinin (ESP) konumsal dağılımının farklı enterpolasyon yöntemleri ile değerlendirilmesi. II. Ulusal Sulama ve Tarımsal Yapılar Sempozyumu, 24-25 Mayıs, İzmir.

Bașbozkurt H, Öztaș T, Karaibrahimoğlu A, Gündoğan R, Genç A. (2013). Toprak özelliklerinin mekansal değișim desenlerinin jeoistatistiksel yöntemlerle belirlenmesi. Atatürk Üniversitesi Ziraat Fakültesi Dergisi, 44(2): 169-181.

Behera S K, Shukla A K (2015). Spatial distribution of surface soil acidity, electrical conductivity, soil organic carbon content and exchangeable potassium, calcium and magnesium in some cropped acid soils of India. Land Degradation Development, 26: 71-79.

Bremner J M, Mulvaney C S (1982). Nitrogen-Total. In: Page, A.L., Miller, R.H., Keeney, D.R (Eds.), Methods of Soil Analysis, Part 2. Chemical and microbiological properties. 2 nd ed. Agronomy 9: 595-624.

Bilen S, Sezen Y (1 993). Toprak reaksiyonunun bitki besin elementleri elverișliliği üzerine etkisi. Atatürk Üniversitesi Ziraat Fakültesi Dergisi, 24 (2): 156-166

Celik P, Dengiz O (2018). Aksendi Ovası tarım topraklarının temel özellikleri ve bitki besin durumlarının belirlenmesi ve dağılım haritalarının olușturulması. Türkiye Tarımsal Araștırmalar Dergisi, 5(1): 9-18.

Ding Y (2011). Research on the spatial interpolation methods of soil moisture based on GIS, International Conference on Information Science and Technology, pp.709-711, 26-28 March, Nanjing, China.

Doğru A Ö, Keskin M, Özdoğu K, Illiev N, Uluğtekin N N, Bektaș Balçık F, Göksel C,, Sözen S (2011). Meteorolojik verilerin değerlendirilmesi ve sunulması için enterpolasyon yöntemlerinin karșılaștııılması, TMMOB Coğrafi Bilgi Sistemleri Kongresi. 31 Ekim-4 Kasım, Antalya. 
Emadi M, Baghernejad M (2014). Comparison of spatial interpolation techniques for mapping soil $\mathrm{pH}$ and salinity in agricultural coastal areas, northern Iran. Archives of Agronomy and Soil Science, 60(9): 1315- 1327.

Ersoy A, Yünsel T Y (2008). Maden rezerv hesapları klasik ve jeoistatistik yöntemler. Nobel Kitabevi, Adana, s. 103.

FAO, 1990. Micronutrient. Assessment at the country level: an international study. FAO soil bulletin by Mikko Sillanpaa. Rome.

Güçdemir i H, Türker $U$, Karabulut $A$, ve Arcak C (2004). Gübreleme teknolojilerindeki yenlikler (Hassas tarım uygulamaları) ve bunun tarımsal üretime etkileri üzerine bir çalıșma. 3. Ulusal Gübre Kongresi. Cilt I. Tarım Sanayi Çevre, 1005-1014. 11-13 Ekim, Tokat.

Heuvelink G BM (2006). Incorporating process knowledge in spatial interpolation of environmental variables. Accuracy 2006 ( 7th International Symposium on Spatial Accuracy Assessment in Natural Resources and Environmental Sciences), pp. 32-47. 5-7 July, Lisbon, Portugal.

Jackson M L (1 958). Soil Chemical Analysis. Prentice Hall, Inc. Engewood Cliffs, NewJersey, USA.

Johnston K, Hoef M, Krivoruchko K, Lucas N (2001). Using ArcGIS geostatistical Analyst, ESRI, New York, USA.

Luo $\mathrm{H}$, He X (2011). An improved inverse distance weighted interpolation method for InSAR tropospheric delay error corrections. International Conference on Information Science and Technology, pp. 480-482. 10 May, Nanjing, China.

Mair A, Fares A (2011). Comparison of rainfall interpolation methods in a mountainous region of a tropical island, Journal of Hydrologic Engineering, 16(4): 371-383.

Nougeira M A, Albino U B, Brandao-Junior O, Braun G, Cruz M F, Dias B A, Duarte R T D, Gioppo N M R, Menna
P, Orlandi J M, Raimam M P, Rampazo L G L, Santos M A, Silva M E Z, Vieira F P, Torezan J M D, Hungria M, Andrade G ( 2006). Promising indicators for assessment of agroecosystems alteration among natural, reforested and agricultural land use in southern Brazil. Agriculture, Ecosystems and Environment, 115: 237-247.

Olsen S R, Cole C V, Watanable F S, Dean L A (1954). Estimation of available phosphorus in soils by extraction with sodium bicarbonate. USDA Circular 939. U.S Government Printing Office, Washington D.C.

Özyazıcı M A, Dengiz O, Aydoğan M, Bayrakı B, Kesim E, Urla Ö, Yıldız H, Ünal E (2016). Orta ve Doğu Karadeniz Bölgesi tarım topraklarının temel verimlilik düzeyleri ve alansal dağılımları. Anadolu Tarım Bilimleri Dergisi, 31(1): 136-148.

Soil Survey Staff (1999) Keys to Soil Taxonomy. USDA. SMSS. Technical Monograph No:19.

Tașan M, Demir Y (2017). Çeltik yetiștiriciliği yapılan arazilerde demir ve mangan içeriklerinin alansal dağılımının farklı enterpolasyon yöntemleri ile belirlenmesi. Anadolu Tarım Bilimleri Dergisi, 32: 64-73.

Temizel K E (2016). Mapping of some soil properties due to precision irrigation in agriculture. Agronomy Research, 14(3): 959-966.

Turan M, Bingöl A F (1 991). Kovancılar-Baskil (Elazığ) arası bölgenin tektonostratigrafik özellikleri. Cukurova Üniversitesi Ahmet Acar Sempozyumu. Bildiriler: 213-227. Adana.

Wang S, Huang G H, Lin Q G, Li Z, Zhangand H, Fan Y R (2014). Comparison of interpolation methods for estimating spatial distribution of precipitation in Ontario, Canada, Int. J. Climatol, 34: 3745-3751.

Wilding L P (1 985). Spatial variability: it's documentation, accommodation and implication to soil surveys. In: Soil Spatial Variability. (Eds: Nielsen, D.R. and J. Bouma) Pudoc, pp. 166-194, Wageningen, The Netherlands. 